Ann. Biol. anim. Bioch. Biophys., 1979, 19 (3 B), 791-794.

\title{
Biosynthesis and turn-over of human intestinal brush border glycoproteins during organ culture
}

par Michèle KEDINGER, H. P. HAURI, Katy HAFFEN

Unité 61 INSERM, 3, Avenue Molière, 67200 Strasbourg Hautepierre.

\begin{abstract}
Summary. The biosynthesis of enzymatic glycoproteins of the brush border of the human jejunum was analyzed by organ culture. ${ }^{14} \mathrm{C}$ glucosamine incorporation was estimated in enzymatic proteins after they were separated by electrophoresis. After $24 \mathrm{hrs}$ of culture, the incorporated radioactivity was found in proteins of high molecular weight, corresponding to the following enzymatic activities : maltase-glucoamylase, lactase, sucrase-isomaltase, enterokinase and alkaline phosphatase. Most of these proteins were already labelled after 5 hrs of culture.

The renewal of enzymatic glycoproteins, analyzed by chase experiments, proved to be extremely slow in culture. This result might be explained by the absence of solubilizing agents in the medium which are usually present in the intestinal lumen.
\end{abstract}

\section{Introduction.}

Little is known about the biosynthesis and turn-over of enzymatic brush border glycoproteins in humans since in vivo studies are impossible, and in vitro investigations have been limited by the short survival of intestinal tissue and the small amount of it obtained by peroral biopsy. These difficulties have been overcome by the development of an organ culture method suitable for intestinal mucosa (Browning and Trier, 1969), and by the use of specimens of mucosa prepared from operation material in addition to peroral biopsies. This study reports methods for isolating and chemically analyzing brush border membranes of explants cultured up to $48 \mathrm{hrs}$.

\section{Methodology.}

Small explants $(2 \times 5 \mathrm{~mm})$ of dissected intestinal mucosa were cultured as described earlier (Hauri et al., 1975). Brush border membranes were isolated and the proteins were separated by electrophoresis on $7.5 \mathrm{p}$. 100 polyacrylamide gel in the presence of 0.1 p. 100 SDS. One-half of the gel was stained for proteins; the other half was frozen and cut in 0.3 or $0.5 \mathrm{~mm}$ slices for subsequent enzyme or radioactivity assay (Hauri et al., 1977). 
In order to demonstrate glycoprotein synthesis, ${ }^{14} \mathrm{C}$ glucosamine was added to the culture medium for various time intervals (Hauri et al., 1977). The basal turn-over of intestinal enzymatic glycoproteins was measured by the pulse-chase technique using ${ }^{14} \mathrm{C}$ glucosamine, ${ }^{14} \mathrm{C}$ fucose and ${ }^{14} \mathrm{C}$ leucine as tracers (Kedinger et al., 1978).

\section{Results.}

1. Protein and enzyme patterns of the brush border membrane. - Representative protein and enzyme scans of the brush border membrane after gel electrophoresis are given in figure 1 ; only the high molecular weight region is shown. The following correspondence of protein and enzyme peaks has been esiablished : protein peak 2 with maltase and glucoamylase activities, protein peak 3 with lactase activity, protein peak 4 with maltase and sucrase-isomaltase activities and protein peak 5 with enterokinase activity. Alkaline phosphatase activity appeared as a broad main peak in the position of protein band 7, but its correspondence was less exact than that obtained for the disacharidases. No known enzymatic activities could be attributed to protein bands 1 and 6 .

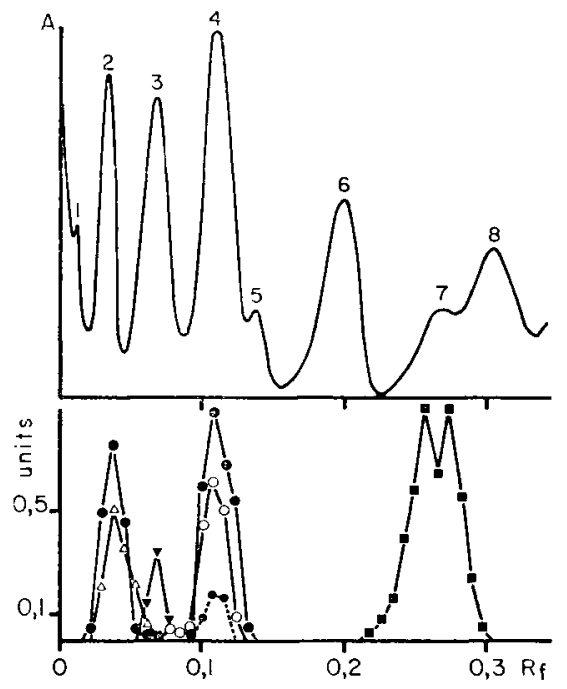

FIG. 1. - Prolein (above) and enzyme (below) patferns of brush border membranes isolated from non cultured jejunal explants

$\bullet-$ maltase ; ०—० sucrase ; $\bullet-$ isomaltase ; $\Delta-\Delta$ glucoamylase ; $\rightarrow \longrightarrow$ lactase ; $\square-$ alkaline phosphatase.

When the protein peaks were compared among themselves at the beginning of the culture and after 24 or $48 \mathrm{hrs}$, there was no obvious qualitative or quantitative change in the protein patterns. Furthermore, the pattern of brush border enzymes did not change during culture and the correlation with protein bands was maintained.

2. Incorporation of ${ }^{14} \mathrm{C}$ glucosamine as a measure of brush border glycoprotein synthesis. - After $5 \mathrm{hrs}$. of culture, hexosamine incorporation was found in the position of pro- 
tein peak 2 (maltase-glucoamylase), peak 3 (lactase), peak 4 (sucrase-maltase) peak 5 (enterokinase) and peak 6. After 24 hrs. (fig. 2), the radioactivity profile was more pronounced, also showing radioactivity corresponding to peak 1, peak 7 (region of alkaline phosphatase) and peak 9.

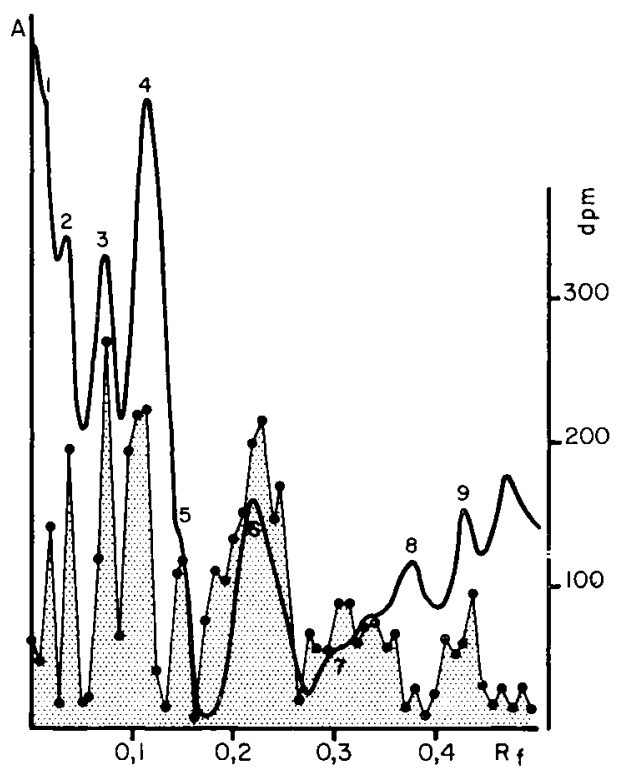

FIG. 2. - Protein and radioactivity (stippled area) profiles ofter ${ }^{14} \mathrm{C}$ glucosomine incorporation during 24 hrs of culture.

3. Turn-over of brush border membrane glycoproteins. - The radioactivity patterns obtained after the pulse period with glucosamine, fucose or leucine were almost identical. As illustrated in figure 3, no significant decrease of radioactivity in the main enzymatic glycoproteins (glucoamylase, sucrase and lactase) was evident during the pulse period whatever precursors were used. Only protein 6 , whose identity remains to be elucidated, exhibited a high relative turn-over with an apparent half-life of 30 hrs.
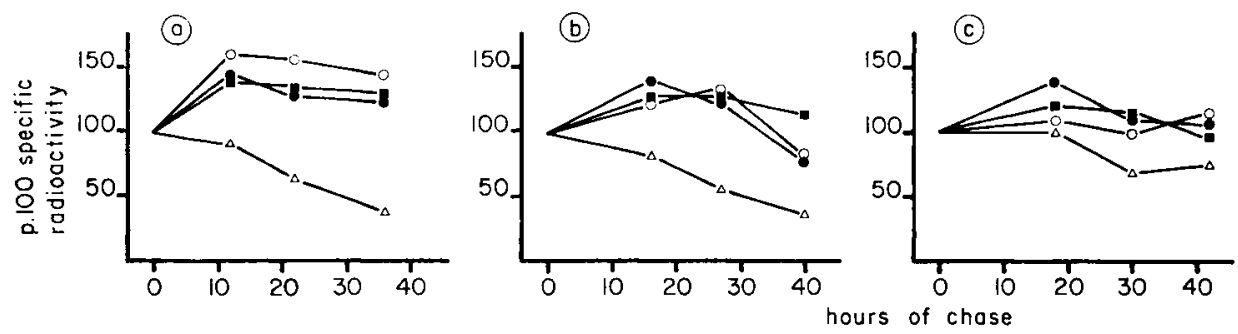

FIG. 3. - Time course of ${ }^{14} \mathrm{C}$ leucine (a), ${ }^{14} \mathrm{C}$ fucose (b) or ${ }^{14} \mathrm{C}$ glucosamine (c) from individual brush border protein bands after various time intervals of chase. The specific radioactivity calculated at the end of the pulse period (8 hrs) was set to 100 p. 100 a glucoamylase ; o sucrase ; 1 lactase ; $\Delta$ protein 6 


\section{Interpretation of the results.}

Although the possibility exists that all radioactivity peaks, except that of sucraseisomaltase, might be contaminated by minor protein bands, the main brush border glycoproteins were probably synthesized during culture. It should be particularly noted that the low molecular weight core proteins, migrating in the distal part of the gel, did not interfere with the high molecular weight enzymatic glycoproteins (Maestracci ef al., 1973).

Degradation rates for the major high molecular weight proteins corresponding to maltase-glucoamylase, lactase-phlorizin hydrolase and sucrase-isomaltase enzymatic activities appeared to be low. These findings were confirmed by double isotope experiments using ${ }^{14} \mathrm{C}$-leucine and ${ }^{3} \mathrm{H}$-leucine as tracers. Furthermore, an unidentified glycoprotein, appearing on the gels next to alkaline phosphatase, exhibited a higher degradation rate with an apparent half-life of about $30 \mathrm{hrs}$., which was similar to the half-life of total glycoproteins as measured in mucosal homogenates. The discrepancy between the turn-over rates of explant glycoproteins and those of individual brush border glycoproteins may be explained by the fact that secreted glycoproteins are mainly mucus components (Kedinger et al., 1978). It is tempting to ascribe the low turn-over rate of brush border enzymatic glycoproteins observed in organ culture to the absence of pancreatic enzymes (Alpers and Tedesco, 1975). This interpretation needs further investigation.

Commission CNERNA Digestion-Absorption/Association des Physiologistes, Paris 5-6 octobre 1978.

Résumé. La biosynthèse des glycoprotéines enzymatiques de la bordure en brosse de jéjunum humain a été analysée en culture organotypique. L'incorporation de ${ }^{14} \mathrm{C}$ glucosamine a été évaluée au niveau des protéines enzymatiques après leur séparation par électrophorèse. Après $24 \mathrm{~h}$ de culture, la radioactivité incorporée se retrouve dans des protéines de poids moléculaire élevé dont la correspondance avec les activités enzymatiques suivantes a pu être établie : maltase-glucoamylase, lactase, saccharase-isomaltase, entérokinase et phosphatase alcaline. La plupart d'entre elles sont déjà marquées après $5 \mathrm{~h}$ de culfure.

Le renouvellement des glycoprotéines enzymatiques, analysé par des expériences de chasse, s'est révélé extrêmement lent en culture. Ce résultat peut s'expliquer par l'absence dans le milieu de culture d'agents solubilisants normalement présents dans la lumière intestinale.

\section{References}

ALPERS D. H., TEDESCO F. J., 1975. The possible role of pancreatic proteases in the turnover of intestinal brush border proteins. Biochim. biophys. Acta, 401, 28-40.

BROWNING T. H., TRIER J. S., 1969. Organ culture of mucosal biopsies of human small intestine. J. clin. Invest., 48, 1423-1432.

HAURI H. P., KEDINGER M., HAFFEN K., GRENIER J. F., HADORN B., 1975. Organ culture of human duodenum and jejunum. Biol. Gastroenterol., 8, 307-319.

HAURI H. P., KEDINGER M., HAFFEN K., FREIBURGHAUS A., GRENIER J. F., HADORN B., 1977. Biosynthesis of brush border glycoproteins by human small intestinal mucosa in organ culture. Biochim. bicphys. Acta, 467, 327-339.

KEDINGER M., HAURI H. P., HAFFEN K., GREEN J. R., GRENIER J. F., HADORN B., 1978. Turnover studies of human intestinal brush border membrane glycoproteins in organ culture. Enzyme (in press).

MAESTRACCI D., SCHMITZ J., PREISER H., CRANE R. K., 1973. Proteins and glycoproteins of the human intestinal brush border membrane. Biochim. biophys. Acta, 323, 113-124. 